\title{
Biblical Reception I, edited by J. Cheryl Exum and David J.A. Clines
}

Sheffield: Sheffield Phoenix Press, 2012 | xviii +422 pages | ISBN: 978-I-907534-70-6 (hardback) $£ 80.00$

In her introduction to George Aichele's edited volume Culture, Entertainment and the Bible (Sheffield Academic Press, 2000), Athalya Brenner described the Bible as "an elitist object-produced, consumed,

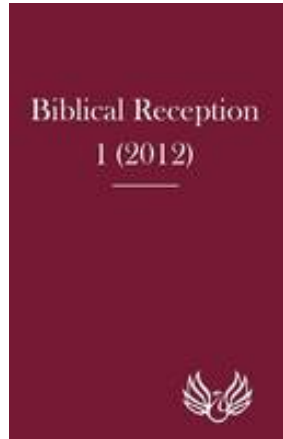
transmitted and studied by elites" (I I). Traditionally, argues Brenner, biblical scholars have striven to sustain a "legacy of secrecy" around both the biblical text and its interpretation, reluctant to share their knowledge with in- 
terested readers who exist outside the hallowed grounds of the Academy (I I). However, she warns, such a move will ultimately prove self-destructive, serving only to maintain biblical studies as an exclusive discipline that captures the interest of an ever-dwindling scholarly group. Agreeing with Brenner's words here, I often wonder how likeminded biblical scholars might address this situation, liberating biblical studies from the chilly and unwelcoming corridors of the Academy, offering instead new possibilities of interpretation that are accessible to all readers of the biblical traditions.

One possible solution to this question is offered up within the delicious new annual by Sheffield Phoenix Press, Biblical Reception, edited by J. Cheryl Exum and David J.A. Clines. This annual strongly embodies Brenner's suggestion, in the essay cited above, that the study of the Bible in conversation with its innumerable cultural representations and receptions can introduce relevant modes of engagement and enjoyment in this discipline, offering the biblical reader (both academic and non-academic) an accessible, creative, and meaningful way to approach these ancient texts ( I I-I2). As the annual's editorial preface notes, while biblical reception history has yet to become a dominant presence in lecture theatres and conference rooms, it is an increasingly popular methodological approach for both scholars and students, its strength lying in the way that it contemporizes and contextualizes the biblical traditions, inviting reflection on their significance within the cultural contexts of everyday life. Maintaining that the academic study of this interpretive methodology has, to date, had "no formal avenue of regular publication," the editors of the annual seek to fill this perceived gap, providing scholarly research that explores the use of the Bible within literature, music, the visual arts, and culture; in other words, "the use of the Bible outside the field of academia" (ix).

This first volume of the annual is divided into six sections, each of which offers one or more essays on biblical engagement with the arts, theory, and culture. In the first section, "Art," we are treated to five essays that explore the visual representations of particular biblical scenes or characters. Each of these essays utilizes one or more artistic works as an alternative tool for biblical interpretation, exploring the exegetical potential that art can have for bringing meaning to even the most well-scrutinized biblical texts. Thus, in her essay "Spot the Difference: Young Men, Angels and the Risen Christ at the Empty Tomb," Christine E. Joynes investigates the meaning of the seldom considered wingless angels in early Christian art depicting the empty tomb narratives, using this artistic convention to unpick the textual ambiguity of 
angelic identification in the interpretive traditions of Mark I6:5. Focusing on early Christian ivories, she considers the ability of these artworks to inspire the viewer's contemplation of the relationship between earthly and heavenly realms and of theological issues surrounding this biblical text and beyond.

Continuing this focus on early Christian art, Mark Finney's essay "Jesus in Visual Imagination: The Art of Invention" considers the "changing face of Christ" (2I) within artistic imagery during the period 200-700 CE. Finney explores the socio-political, cultural, and imperial influences that shaped the portrayal of Christ in a way that had profound effects on later Western art. Scrutinizing textual and archaeological evidence to glean clues pertaining to Jesus's physical appearance, he considers the symbolic and aesthetic qualities of Jesus's portrayals in Roman and early Byzantine art and iconography, suggesting that these images encapsulate a strong relationship between Christianity and imperial government, which affirmed the divinity and imperial majesty of both emperors and the saviour Christ.

Attending to later art works, Laura Greig Krauss and Sara Kipfer both consider artistic representations of texts from the Hebrew Bible. In her essay "Restoring Hagar: Rembrandt van Rijn's Painting Abraham Dismissing Hagar and Ishmael in the Victoria and Albert Museum, London," Krauss focuses on a painting by Rembrandt, which she argues ought to be understood as a depiction of Abraham's dismissal of Hagar in Gen 2I. Seeking "interpretive keys" to Rembrandt's "innovative hermeneutic" of the biblical text (65), she leads the reader through careful analyses of both the biblical text and Rembrandt's multi-religious context of seventeenth-century Amsterdam, arguing that the painting displays Rembrandt's own unique re-reading of the biblical narrative in light of his theological predilections, which were firmly rooted in his socio-religious milieu.

While other essays in this section of the annual focus solely on visual art works, Ela Nutu's essay "Salomé in Text and Performance: The Bible, Wilde and Strauss" looks beyond the canvas to consider the representations of Salomé found in art, literature, and opera from the late nineteenth and early twentieth centuries. Investigating the "metamorphoses" (44) between the biblical text and its literary and artistic afterlives, Nutu traces the development of Salomé as iconographic and literary character throughout this fin de siècle period within seminal works such as Oscar Wilde's play Salomé, Richard Strauss's opera of the same name, and various captivating portrayals from artists such as Aubrey Beardsley and Gustave Moreau. Along the way, we are invited to consider the transformation of this biblical figure from a 
rather monochrome maiden into a vivid, bejewelled, and sexually decadent icon of exquisite depravity. Nutu's essay thus effectively highlights the potency and staying power of certain biblical characters' afterlives.

Moving into the "Film" section of the annual, two essays are offered which both, in different ways, reflect upon the engagement between contemporary film and biblical themes and characters. In her essay "The Cinematic Afterlives of Jesus, the Messiah," Vivienne Westbrook explores the complexities of the "cinematic Jesus" (I I I), arguing that, despite efforts to elide the sacredness and secularity of Jesus in some recent cinematic works, filmic images of the crucified body of Jesus cannot but position his character within a sacred realm, thereby elevating him beyond other more secular film heroes. Meanwhile, looking beyond cinema that explicitly retells New Testament traditions, Jayhoon Yang revisits the popular parable of the Prodigal Son (Luke I 5:II-32), reading this parable in light of the Korean film Secret Sunshine. While the film does not make explicit reference to the parable, such a reading strategy, suggests Yang, offers unconventional yet viable insights into this account, focusing as it does on the oft-neglected theme of the father's persistent love for both his sons. These two essays sit nicely together in this section, their different methodological tactics presenting two alternative, and equally fruitful, approaches to studying the Bible in/and film.

The next genre of cultural texts we encounter in the annual is music. Within this section, three essays are provided which each explore music as an interpretive medium for approaching biblical traditions. In her essay "Moses and the Exodus in Italian Opera," Helen Leneman considers the lyric power of Giacomo Orefice's opera Il Mosè ( I 905). Through her intricate explication of its musical and textual landscapes, Leneman vividly depicts this opera's dramatic interaction with the biblical Mosaic traditions, noting the ways that both Orefice's melodies and lyrics add new depths of meaning to this ancient story. In particular, Leneman's examination of Miriam's characterization in the opera offers a welcome affirmation of the way that cultural afterlives of biblical women have the potential to bring much needed depth and energy to their characters, breathing into them a new and vivifying significance.

In a similar vein to Leneman, Siobhán Dowling Long's essay “The Sacrifice of Isaac: Tales of Heroism and Murder in Two Compositions by Benjamin Britten" likewise considers ways in which musical retellings of a biblical tradition can serve as a valuable interpretive lens (or amplifier) through which to see (and hear) the biblical text anew. Focusing on two compositions by Britten, both based around the Sacrifice of Isaac tradition (Genesis 22), Long, 
like Leneman, presents a fascinating analysis of music's ability—through its lyrics and its sounds - to reflect upon and add new insights to oft-told biblical traditions. This topic is again taken up by William Goodman in the final essay of this section, "Nothing Compares: Sinéad O'Connor's Theology." Goodman examines some of O'Connor's song lyrics from her 2007 album Theology, which she has adapted from Hebrew biblical psalms and poetry. Focusing on both her lyrics and musical delivery, he carefully compares each biblical passage with its "afterlife" in the album, drawing upon O'Connor's own religious and personal background to understand her use of biblical material as a medium for expressing concerns about love, justice, relationships, and faith. Taken together, these three essays demonstrate very effectively the potential power of music to explore and elucidate the biblical traditions through a medium that extends beyond the written word.

In the next section, "Literature," we are treated to four essays which all consider different strategies for using literary works and theories as hermeneutical tools within biblical interpretation. Richard Briggs's wonderful discussion, "Reading Daniel as Children's Literature," invites us to consider the interpretive advantages of reading the book of Daniel $\mathrm{I}-7$ as a story for children; such a strategy, he argues convincingly, brings new insights and understandings to this ancient text that can be too often overlooked by cynical adult eyes.

Following this, Susanne Gillmayr-Bucher and Lina Sjöberg both take intertextual approaches to the biblical narratives, each of their essays offering up different potentialities that can arise from reading biblical texts alongside other, more contemporary material. In her essay "Ruth: Images of an Unfulfillable Longing," Gillmayr-Bucher examines the various engagements of twentieth-century German poetry with the book of Ruth, observing that these poems focus upon particular themes within this biblical narrative to reflect upon contemporary political and social contexts. Meanwhile, Laura Sjöberg demonstrates beautifully the way in which secular literature can function as a source of interpretive inspiration, offering new insights into biblical narratives. Focusing on the Sodom and Gomorrah tradition (Gen I8:16I 9:29), she uses a story by Swedish author Torgny Lindgren as a hermeneutical lens through which to reconsider the salty fate of Lot's wife. Sjöberg describes her method of reading here as a "trialogue" (27I) - the reader in conversation with both the biblical text and the cultural text (be it literature, art, film, etc.) in order to discover fresh layers of meaning within the words, ambiguities, and gaps so often found within Bible stories. 
Finishing off this section, and tying together some of the themes addressed in the previous three essays, Anthony Swindell considers "Mapping the Afterlife of Biblical Stories." Swindell discusses three recent works on the literary reception of biblical traditions, arguing that they affirm the cumulative quality of reception history traditions, which can serve as a "vehicle through which an ancient sacred text orientates itself towards the future" (28I). This, suggests Swindell, contributes to a "dialogical process" (28I) that offers a valuable alternative to more abstract discourses of theological or philosophical reflection.

Our foray into different genres of cultural texts takes a brief rest at this point in the annual to introduce an essay on "Theory" within the field of reception history. Brennan W. Breed's intriguingly titled piece "Nomadology of the Bible: A Processual Approach to Biblical Reception History" considers the theoretical underpinnings of biblical reception history. Arguing that scholarly attempts to distinguish "original" biblical texts from their numerous "receptions" are misguided, Breed suggests instead that it is more fruitful to consider the Bible not as a static object but as a "continuous process," which can move nomadically between and around different cultural contexts and which has the potential to manifest multiple, multifaceted meanings and significances. Compared to a "sedentary approach" to biblical reception history, which organizes biblical reception studies around a particular external category (e.g., Christian studies, medieval studies, Bible in film, etc), Breed argues that a nomadic method uses only "imminent criteria" to delineate the parameters for a specific piece of biblical reception history, thus allowing these parameters to be more porous and fluid than would otherwise be possible. This is an interesting theoretical approach to biblical reception studies and worth reflecting upon, particularly given its place within this annual whose format (dividing essays into sections according to artistic genre) appears to follow the "sedentary" organizational approach of which Breed is critical. As an effective theoretical reflection, however, the essay may have had more impact had it provided a more detailed example of the nomadic approach in action, thereby granting readers a helpful and informative comparison to the sedentary stance.

Resuming our journey through genres of biblical engagement, we then come to the final part of the annual- "Culture." The five essays in this section all engage in some way with cultural responses to or (mis)appropriations of the biblical text within a range of socio-cultural contexts. Thus, in Katie B. Edwards's fascinating study of the "Sporting Messiah" phenomenon, we 
are treated to a rich gallery of Jesus and Christ imagery that has been used in sports advertising and imagery. Here, sporting figures such as Wayne Rooney and David Beckham are presented in Christ-like messianic poses that, according to Edwards, serve to affirm their status within contemporary culture as god-like male warriors on a mission to bring salvation to the nation. These images are both fascinating and at times disconcerting; certainly, they have not been without their critics and opponents, particularly from within religious establishments that take exception to the trivializing of imagery that they argue carries such heavy theological and sacred weight. And yet, what is equally if not more perturbing is, as Edwards notes, the power of these images to communicate and reaffirm prevailing cultural ideologies that tie together particular brands of masculinity, nationalism, and militarism.

Another essay in this section that explores explicit biblical appropriation within cultural and public life is Amy C. Cottrill's "Pray for Obama: Psalm I 09:8': A Reception Critical Approach to the Violence of the Psalms." Cottrill examines those American anti-Obama bumper stickers whose outwardly benign slogans encourage the use of Ps I09:8 as a "prayer for Obama": "May his days be few in number, may another take his office." As a study in biblical reception, she argues, these expressions of "violent prayer" (367) within public political discourse provide a valuable means of focalizing vocabularies of violence-both tragic and comedic — within biblical texts such as Pss Io9 and I37. This is particularly important, she stresses, given that the psalmists' violent voices are often ignored or inadequately addressed within conventional Psalms scholarship. Cottrill's essay provides a textual analysis of these two psalms, using as her hermeneutical foreground the socio-political undercurrents made visible in these infamous (and insidious) bumper stickers.

Continuing with this socio-political focus in biblical reception, Yairah Amit's fascinating essay "The Study of the Hebrew Bible in Israeli Education" traces the development of Biblical Studies as a curricular subject area within Israeli Education. Amit's diachronic approach follows the cultural political trajectories that have seen state school-based biblical studies deteriorate in both quantity and quality to the point that it has become "a subject scorned" (396) within the education system, which then has repercussions on wider cultural conceptualizations of biblical significance. This, Amit suggests, raises a number of cultural and religious questions, not least of all the assonance/dissonance between Jewish and Israeli identities and the shaky future of biblical engagement, biblical literacy, and the perceived relevance of the biblical traditions within state education and wider secular Israeli culture. 
Amit's exploration of cultural engagements with the Bible within a particular geographical and historical milieu is likewise addressed in Kevin M. McGeough's essay "Negotiating the Real and the Hyperreal: NineteenthCentury Experiences of the Bible in the Context of Ancient Near Eastern Discoveries." Using nineteenth-century British culture as a case study, McGeough traces the influences of colonial encounters with Near Eastern archaeology and the Victorian visual arts on popular biblical reception. His discussion of the Victorian fascination with scholarly and artistic orientalism draws into play ideations of biblical historicity at this time and the ways in which these were intricately connected to the growing interest in and prominence of Near Eastern archaeology, which, through its own cultural reception, served to "bring the Bible out of the realm of myth and into the realm of history" (40I).

The fifth essay within this section of the annual by Amanda Dillon takes a step away from surveying biblical reception within a particular historical or political context to examine and take to task a relatively new paradigm of biblical reception-Manga Bibles. Utilizing a feminist critical hermeneutic, Dillon compares four recently published English-language Manga Bibles and their representation of female characters in the book of Judges. Throughout her discussion, she demonstrates the propensity of this hugely popular yet notoriously sexist comic book genre to re-inscribe the androcentric biases given voice within this biblical text; female characters are either elided completely or reduced to predictable stereotypes of feminine vulnerability, weakness, or duplicity, while episodes of male violence are essentially ignored. Dillon's essay is a valuable addition to the annual, in its affirmation of the comic book genre as a new and important addition to biblical reception studies. I was curious, however, about the editorial decision to include it in the "Culture" section of the annual rather than in the section focusing on literature. Perhaps this reflects the still highly contested definition of "literature" within literary and cultural studies. To my mind, though, this engaging essay would fit comfortably in either category.

Overall, this annual was a treat to read, packed as it was with fascinating, innovative, and inspiring examples of the sheer potential of biblical reception studies. For scholars, it provides just a glimpse of the innumerable and rich possibilities that engagement between biblical texts and their multifaceted afterlives can bring to the discipline of biblical studies. For students and interested readers of the biblical traditions, it will also serve as an inspirational springboard, capturing attention and inviting participation in a broad and 
vibrant dialogue that can be encountered well beyond the confines of the traditional Biblical Studies Academy. And therein, I believe, lies its greatest strength.

Caroline Blyth

University of Auckland 